\section{О некоторых особенностях перехода на сортиментную технологию}

\author{
К. К. Демин ${ }^{1}$ \\ Ассочиачия НТС ЛПК по Республике Карелия
}

\begin{abstract}
АННОТАЦИЯ
В статье рассмотрены практические вопросы перехода лесозаготовительного предприятия на сортиментный способ заготовки древесины на лесосеке, причины перехода и технико-технологические возможности его осуществления.
\end{abstract}

Ключевые слова: сортиментная технология, объем заготовки, лесозаготовительные машины, инвестиนุиน.

\section{SUMMARY}

The practical questions of transferring the harvesting enterprises to the sorting methods of logging at the felling areas, the motives and technical and technological possibilities of its practical introduction are discussed in this article.

Keywords: cut to length methods, cutting volume, harvesting machines, investments.

В последние годы на лесозаготовительных предприятиях Республики Карелия все более активно внедряется технология заготовки сортиментов непосредственно на лесосеке. В 2001 году объем заготовки сортиментов составил 28,6 \%, в 2003 году - 32,3\%. При этом применяются, как правило, два набора машин и механизмов:

- $\quad$ комплект мотопил + форвардер;

- харвестер + форвардер + мотопила для освоения деревьев, валка которых харвестером затруднена.

Основные причины перехода на сортиментную технологию:

- дефицит рабочих кадров (учитывая это, предполагается почти полная машинизация лесосечных работ, только небольшая часть древесины заготавливается с помощью трактора ТДТ-55А - неудобные и заболоченные площади);

- престижность профессий машинистовоператоров и, как следствие, возможность привлечь молодежь;

- $\quad$ значительное повышение производительности труда на лесосечных работах и вывозке леса;

\footnotetext{
${ }^{1}$ Автор - генеральный директор Территориального представительства Ассоциации НТС ЛПК по Республике Карелия

(c) К. К. Демин, 2003
}

- обеспечение, с учетом сказанного выше, экономической устойчивости и стабильности работы предприятия.

Рассмотрим на примере одного из предприятий Карелии сравнительную эффективность хлыстовой и сортиментной технологий заготовки древесины.

Годовой объем лесозаготовок - 170-180 тыс. м³. Предприятие работает в арендованном лесосечном фонде, расчетная лесосека обеспечивает заготовку указанного объема. Средний запас $-150 \mathrm{~m}^{3}$ на 1 га. Средний объем хлыста - 0,29 $\mathrm{m}^{3}$. Существующий технологический процесс: заготовка и вывозка хлыстов на нижний склад, раскряжевка хлыстов и отгрузка сортиментов потребителю.

Значительная доля лесопродукции реализуется на внешнем рынке (так, в 2001 году на экспорт было отгружено почти $50 \%$ пиловочника, одна треть балансов еловых, 10 \% балансов сосновых и все березовые балансы).

Основной объем заготовки сортиментов на лесосеке (валка, обрезка сучьев, раскряжевка) на предприятиях Карелии осуществляется с помощью бензиномоторных пил типа «Хюскварна» или «Штиль». Средняя производительность лесоруба на этих операциях в 2001 году составила $1780 \mathrm{~m}^{3}$ (за год). Следовательно, для годовой заготовки 170-180 тыс. м ${ }^{3}$ рассматриваемому предприятию потребовалось бы 100 человек вальщиков, владеющих этими операциями, а это более чем четвертая часть сегодняшнего личного состава предприятия.

Разумеется, это нереально, поэтому руководством предприятия было принято решение о внедрении на лесосечных работах полностью машинизированных комплексов в составе «харвестер + форвардер».

В России сегодня не производятся машины типа «харвестер». Форвардеры начали изготавливать Арзамасский машиностроительный завод, Орловский завод дорожных машин и Минский тракторный завод (Беларусь). Однако они сегодня не пользуются большим спросом у лесозаготовителей. Учитывая сказанное и наличие в республике сервисного центра фирмы «Тимберджек», руководители предприятия остановили свой выбор на машинах именно этой фирмы. Исходя из этого, для выполнения полностью машинизированных лесосечных работ рекомендуются: харвестер «Тимберджек»- 4 единицы; форвардер «Тимберджек» -5 единиц.

Годовая производительность на списочную машину: харвестер - 40 тыс. м³ коэффициенте сменности - 3. Потребность рабочих: машинисты-операторы харвестера - 10 чел.; машинисты-операторы форвардера - 12-13 чел.

Заметим, что в Карелии предприятия, выполняющие заготовку сортиментов, применяют именно эти марки машин. 
Кроме того, для освоения отдельных деревьев, которые невозможно обработать харвестером, предусматривается иметь двух лесорубов, оснащенных мотопилами (валка, обрезка сучьев, раскряжевка), и для разработки крайне неудобных участков лесфонда рекомендуется организовать звено на базе трактора ТДТ55А (ТЛТ-100) в составе 6 человек.

Рассмотрены варианты применения различных автопоездов для вывозки сортиментов и проведены соответствующие расчеты.

Для конкретных условий на вывозке сортиментов рекомендуется автопоезд ТМ-4502 + ТМ3-8966-010 (базовая машина КамАЗ).

Учитывая приведенные выше условия и исходные данные, рассчитана сравнительная экономическая эффективность сопоставляемых технологий.

Ниже приводятся основные результаты расчетов. Потребные инвестиции для перехода на сортиментную заготовку древесины - 95017 тыс. руб.

Основные фонды предприятия по сопоставляемым вариантам:

- $\quad$ заготовка хлыстов - 16133 тыс. руб.;

- $\quad$ заготовка сортиментов - 101270 тыс. руб.

В связи с этим возрастает налог на имущество с 298 до 1835,7 тыс. руб.

Переход на сортиментную технологию приводит к снижению чистой прибыли, получаемой предприятием, почти на 3 млн. руб. Снизится также рентабельность производства (с $21 \%$ по базовому варианту до $16 \%$ по новому).

В то же время работа предприятия по новой технологии безубыточна и будет приносить значительный ежегодный доход в размере 13500 тыс. руб. чистой прибыли.
Внедрение сортиментной технологии также позволит предприятию в определенной мере решить вопрос дефицита рабочей силы. Сокращение общей численности основных рабочих составляет 76 чел., в том числе по фазам работ: на лесосечных работах - 31 чел., на вывозке древесины - 9 чел., на нижнем лесоскладе - 36 чел.

Результаты анализа чувствительности позволяют сделать вывод о достаточно высокой степени устойчивости предприятия к основным негативным факторам, влияющим на его финансовый результат, таким как снижение цен на лесопродукцию и увеличение цен на сырье и материалы, что, на наш взгляд, подтверждает целесообразность перехода предприятия на сортиментную технологию.

\section{СПИСОК ЛИТЕРАТУРЫ}

1. Основные направления деятельности правительства в области развития лесопромышленного комплекса Республики Карелия на период 20012004 гг. Петрозаводск, 2002. С. 75.

2. Жуков А. В., Иевинь И. К. и др. Заготовка сортиментов на лесосеке - технология и машины. М.: Экология. 1993. С. 311.

3. Демин К. К., Мощевикин П. Е., Васильев И. А. О технической политике в области лесозаготовок // Ресурсосберегающие технологии лесного комплекса: Тез. докл. Республиканской научнопрактической конференции. / КарНИИЛП. Петрозаводск,. 1998. С. 3.

4. Сравнительная эффективность хлыстовой и сортиментной заготовки древесины: Отчет по НИР. / Рук. К. К. Демин; КарНИИЛП. Петрозаводск, 2002. 46 c. 